\title{
The Extent of Technology Infusion in the Junior Secondary School Math \& Science Curriculum: Students Views
}

\author{
End Salani*, Mavis B. Mhlauli \\ Department of Primary Education, Faculty of Education, Private Bag 00702, University of Botswana, \\ Gaborone
}

*Corresponding Author: End Salani, Department of Primary Education, Faculty of Education, Private Bag 00702, University of Botswana, Gaborone

\begin{abstract}
Computer Technology infusion is the use of computer applications and software in classroom instructional practices. Infusion of computer technology in teaching has been viewed as facing challenges deriving from teachers' lack of computer technology skills and inadequacy of computers. It has been however, reported that students' collaboration and interactive skills tended to improve in classes taught with the use of computers compared to those taught through the orthodox methods. Performance in the three year JC results over the last seven years had also been reportedly declining (BEC JC results, 2010-2017) across various subjects in Botswana junior secondary schools, despite the computer infusion program that hit the school system seven (7) years ago. It is on the basis of the aforementioned that the purpose of this study was to find out students' views on the extent to which computer technology is integrated across math and science subjects. The study employed a quantitative survey design and used open ended questions for triangulation purposes. Form three students formed the sample of this study and it was drawn through simple random sampling technique from the South East Educational Region schools. The data was collected through the use of a questionnaire and qualitative methods were used to analyse the data. For quantitative data processes (closed ended questions), a statistical program called Statistical Package for the Social Sciences (SPSS version 23) was used for data entry and analysis of the results. Descriptive and Inferential statistics were used in the data analysis. The data from open ended questions was analysed thematically. The findings from this study revealed that most of the students believed computer technology infusion helped them to develop cooperative skills and creativity which could possibly result in increased motivation to learn concepts with understanding. The study findings had implications for research and practice as it provides unique and comprehensive data that will lead to insight for curriculum designers, policy implementers and instructional leaders on effective computer technology infusion.
\end{abstract}

Keywords: Secondary Education, Collaboration and Interactive Skills, Cooperative and Creativity, Computer Technology Infusion, Classroom Instructional Practices

\section{INTRODUCTION}

Botswana junior secondary schools have witnessed the inclusion of technology objectives in various subjects over the last decade including mathematics and science. However, the effective computer use by both teachers and students in Botswana junior secondary school curriculum remains an area of interest for further exploration. Very few researches had been conducted in Botswana schools with findings indicating that teachers were given inadequate in-service training to the detriment of effective use of computers for improved teaching and learning processes (Mooketsi, 2000) and that computers in schools were of limited quantity worse of all designated for general purpose- computer awareness or computer studies programmes (Letlotlo, Kyeleve, and Liu, 2002). The Ministry of Basic Education (MOBE)in its pursuit to align the education system to the evolving technological practices introduced Computer Awareness subject for junior secondary schools in 2008. The subject was rolled out to all junior secondary schools of Botswana in 2010 to develop literacy and understanding of the use of Information and Communication Technology (ICT) in the world and every sphere of life in order to make students appreciate technology and acquire technological skills including basic skills in handling tools (Botswana Three Year Junior Certificate Curriculum Blueprint, 2010). Currently each school has a computer laboratory with 20 computers for use by over 700 students per school manned by a Senior Teacher Grade I Computer Awareness who is assisted by other members of staff on voluntary basis. 
The Extent of Technology Infusion in the Junior Secondary School Math \& Science Curriculum: Students Views

The introduction of Computer Awareness in junior secondary school was in line with some of the Revised National Policy on Education, [RNPE]'s (1994) goals such as recommendation 32(c) and 42(f) which state that each student should take a basic Computer awareness course and that all schools should be allocated enough computers to enable all students to develop computer skills respectively. The use of technology in the school curriculum is undoubtedly a valuable tool in this technologically advanced era. For example, the National Council of Teachers of Mathematics outlined the following reasons why technology is used in teaching of mathematics:

- technology could support investigation by students in every area of mathematics

- students have a greater chance of diverting their attention to decision making, reflection, reasoning and problem solving

- Access to technology allows students to work productively and reflectively when doing exploratory work (NCTM, 2000, pp.3\&24).

This clearly supports the assertion that technology plays a pivotal role in the modern society let alone the school curriculum. In 2010, the department of Curriculum and Development, revised the school curriculum to include objectives for infusion of Computer technology across various subjects and table 2 (see Appendix D) gives a summary analysis of those subjects that have profound objectives addressing technology infusion (Junior Secondary School Curriculum Blue Print, 2010). The subjects are both from core (Mathematics, Science, Social Studies, and English) and optional (Religious Education, Art, Commerce and Accounting, Commerce and Office Procedures and Design \& Technology) brackets. The question now is whether or not teachers integrate computers in their respective subject areas given that computers are not enough and also most of the teachers lack the necessary skills to competently integrate computer technology in their subject areas? The numbers of computers in junior secondary school and the unavailability of continual professional development of teachers in this dynamic technological world are in contravention of recommendation 42(f) and 32(c) of RNPE (1994) and Botswana Vision 2016's pillar of an educated and informed nation which stresses that "Botswana would have sought and acquired the best available information technology..." (p. 5).

The introduction of computers in junior secondary schools is in accordance with global education technological benefits of a computer use in instruction which among others includes provision of an interactive learning environment. Forcier (1999) supports the above contention as he says "Technology will provide students with access to information and the tools to produce substantial work...The most exciting use of technology by the students of the future will be the production of meaningful work"(p.19). The foregoing arguments attaches a significant value to computers and classroom learning which is an academic strategy that could form the basis of a learner centred classroom environment as enshrined in the RNPE(1994) recommendation 3.3(c) which states that the objectives of national education at school level is to improve quality instruction. This study therefore intends to establish the extent of computer infusion in the teaching of some subjects at junior secondary school level, with the view of establishing good practices geared towards improving the quality of teaching. The findings could provide insight into the challenges that teachers and students face in their pursuit to interact with the limited available computers and subsequently solutions might be provided with the view of addressing the identified gaps and challenges. The following research questions guided this study:

- What are students' beliefs about computer infusion in the classroom instructional practices?

- What challenges do students face during learning through computer infusion approach?

- What recommendations do students make for effective implementation of computer infusion in the classroom instruction?

\subsection{Literature Review}

According to Ruthven (1996), there have been spectacular advances in personal computer technology since late 1970s and Balacheff and Kaput (1996) observed that a unique feature of effective computer based learning environments as compared to other types of learning was their intrinsically cognitive 
The Extent of Technology Infusion in the Junior Secondary School Math \& Science Curriculum: Students Views

character. The history of computers in the secondary schools all over the world goes back to the late seventies and early eighties of the $20^{\text {th }}$ century (Dagiene, Dzemyda and Sapagovas, 2006). However, in Botswana, the official beginning of computer awareness experience as a subject in junior secondary schools can be dated back to 2008 (Junior secondary school Curriculum Blue print, 2008) while at senior secondary schools it dates back to 1992 (Mmatli, 1992; Serumola, 1992). Furthermore, the concept of computer infusion was introduced among different subject areas of the school curriculum in 2010 with the view of making students and teachers appreciate the benefits of technology and its applicability across the curriculum. This is also an indication that computer infusion is a relatively new concept in the Botswana education system and there are definitely indisputable challenges deriving from the infusion process. One has to observe that there is more to the infusion process than the financial resources the government provides in order to drive the programme as remarked by Dagiene et al. who said "The successful introduction of Computer technologies in schools and learning is determined not only by money invested in, but also a change of mental habit and promoting cooperation among researchers in educational technology, policy makers and teachers" ( $p$. 11). This therefore calls for deliberate action on the part of implementers as computer infusion was introduced during a time when the Botswana education system was undergoing curriculum changes in terms of paradigm shifts from traditional methods of teaching to learner centred approaches. Hereafter, there is a need for one to appreciate the fact that promoting curricular change, shifting the focus from knowledge as a set of content and especially from technical knowledge as infusion of process and skills is a very difficult task (Dagiene et al., 2006). Moreover, According to Boris (2004) the so-called computer revolution in schools never took place as expected. He attributed the failure to integrate computers into the school curriculum to teachers' instructional and technology beliefs. In the words of Boris (2004, p.1\&3): "Teachers' instructional beliefs are to a certain extent responsible for such a disappointment because a significant number of teachers do not support the principle that technology is a powerful tool for teaching and learning as recommended in current curriculum guidelines...Many reasons have been offered as an explanation for low computer infusion which includes lack of supporting teachers' beliefs, traditional teaching practices, lack of teacher training and not enough instructional preparation time". Cornu (1995) also indicated that computer technologies were usually simply added to other topics in schools, not really integrated. A number of studies discussed below seem to indicate that lack of teacher's supporting beliefs appear to be the major factor in the slow paced infusion of computers in schools:

\subsection{Technology Use in the Classroom Instruction}

A computer, which is one of the most powerful technological tools in the modern classrooms, has the potential to dramatically enhance students' educational experience. As correctly pointed out by the National Research Council (2003), they said "Computer Assisted Education is interactive and therefore captures students' interest better than one-way communication such as lectures or videotapes" (pg. 22). Also Kaino and Salani (2004) pointed out that some educationists consider the use of technology in instruction as the only way to go if not a substitute for conventional teaching and learning methods. To justify the above, reviewed literature in Botswana and elsewhere has observed the unequivocal value of computers in the four corners of the school environment as Taylor (1980) remarked "for the foreseeable future, computers will play an increasingly important role in human learning" (p.18). Supporting the above argument, in Maddison's (1983, p.vi) words, he said "...education has always since my boyhood in the city been central in a more specific sense to the future of society beneath the impact of the revolutionary changes which science and technology are bringing about in our lives". This therefore calls for a dynamic teacher who is willing to move with technology times and employ those classroom approaches that nurtures students' use of computer technology. Ritzhaupt, Dawson and Cavanaugh's (2012) study on factors influencing student use of technology in K-12 classrooms established that teacher's level of education and experience teaching with technology positively and significantly influence students' use of technology. This could be interpreted to mean that how a teacher integrates technology into classroom explained how frequently students use technology in a school setting (Ritzhaupt et al, 2012). Moreover, the above argument is clearly indicative that teachers' technological content knowledge is fundamental in that students tend to get inspiration from their teacher, as a result developing desirable attitudes towards technology use. In support of the preceding arguments, various researchers (Zimmermann and Cunningham, 1991; 
The Extent of Technology Infusion in the Junior Secondary School Math \& Science Curriculum: Students Views

Cook, 1985; Benwell, 1986; Ahmad, Corbett and Rogers, 1985) have showed that computers were capable of providing an interactive environment and that students taught through computers develop enthusiasm and positive attitudes leading to increased understanding of the subject matter and its processes. In Mooketsi' (2000) study on effective use of computers in teaching mathematics in Botswana senior secondary schools, he found that those students who were taught certain concepts and skills that integrated the use of computers performed significantly better than those taught using traditional approaches. On the contrary Mooketsi's (2000) findings also revealed that computer related learning materials did not improve students' attitudes of enjoyment and confidence in mathematics. This study attempted to find out students and teachers' beliefs about technology use which could provide some of the answers to why students' use of technology tend not to influence their attitudes and confidence in the use of technology. Kadisa (2009) also conducted a study on the use of computers and extent of computer infusion in the learning of preschool children in Botswana and she found that there was computer usage in preschool but infusion of computers was not well implemented. Furthermore, those teachers who integrated computers in learning focused in mathematics and science oriented themes only. In support of Kadisa's findings, Du Plessis and Webb's (2012) study on teacher perceptions of the challenges related to implementing Information and Communication Technology (ICT) found that there was a need for on-going training and support for teachers in ICT, adding that these barriers appear to have not allowed the teachers and schools to go beyond an initial infusion phase. This is consistent with Garegae's (2003) finding which indicated that computer infusion is appropriate for math and science subjects only by just looking at the examples of topics teachers listed as the ones they integrate (alphabets, animals, numbers, whether). On the contrary other researchers (Benwell, 1986; Wright and Wilson, 2011; Kaya, 2012) have indicated that technology offers a remarkable chance to bring the whole world into the social studies classroom and provide an excellent method of carrying out remedial and reinforcing work in language learning. It is therefore in the interest of this study that the students' views on the extent to which teachers address the objectives on technology use in their respective subject areas (Math and science) was established considering that studies done in Botswana were biased towards the science subjects suggesting that technology as a science would be more relevant to math and science subjects only. Challenges encountered by students were established and suggestions on thoughtful ways to provide a technology enhanced classroom environment suggested.

\subsection{Teacher Support on Computer Infusion}

Teacher support in schools is proffered as a form of professional development which is the process of obtaining the skills, qualifications, and experience that allow one to make progress in their career (Rundell, 2009). Several studies on effective use of computers have singled out teacher support as a major contributory factor to effective infusion of computers in the teaching and learning environments. For instance, Wright and Wilson's (2011) study on teachers' use of technology found that teachers who had continued professional development tended to engage students in using technology and also had the support from their school community. This clearly shows that a teacher who is not well grounded in computer technologies is will likely to disregard the computer value in the classroom instruction and eventually develop unfavourable attitudes towards computer infusion in the subject area. In yet another study by Bozkurt (2011), a classroom observation evaluation of elementary teachers' use of technology, it was observed that teachers who had received in-service training purposefully integrated technology into their lessons and they generally understood how to select an appropriate technology for their particular teaching purpose. Although this finding is focused on primary level, it was critical to this study in the sense that the extent of computer infusion was established and compared to the literature that suggest that the in-service training has a direct bearing on effective computer infusion or infusion by teachers. To stress on the importance of in-service support in technology, Johnson, Maddux and Liu (2000) said "Through our involvement in teacher training program, we have come to recognise that an important part of bringing pre-service and inservice teachers to a point where they can effectively integrate information technology into the classroom is to provide them with a variety of good examples" (pg.1). This suggests that teachers in their pursuit to infuse computers in their subject areas they need to know roughly what to teach at any given time and a variety of practical arguments to guide them if they are to involve students meaningfully with computers. By the same token, Okojie, Olinzock and Okojie- Boulder (2006) in 
their study on technology infusion observed that the problem of integrating technology into teaching and learning process had become a perennial one. Their findings showed that technology infusion was narrowly perceived and that such a perception might hinder teachers' understanding of the scope of technology in education. In Sabzian and Gilakjani' (2013) study that examined how teachers understand the use of computer technology resources in English language teaching, it was revealed that simply introducing computer technology resources does not guarantee teachers' use of these in practice. This clearly suggests the need for effective guidance, support and training for teachers in integrating computer technology resources into language instruction through direct practical experience.

Furthermore, Eristi, Kurt and Dundah's (2012) study on teachers' views about effective use of technology in classrooms, argued that although teachers were willing to use technology in their courses they needed constant support regarding technology in their courses. This is however, not exhaustive in terms of why teachers fail to use technology as Eristi et al. (2012) outlined the following as some factors barring teachers from using technology: lack of time for teachers to plan and apply new technology and their attitudes towards technology which are consistent with findings by other researchers (Nkhwalume, 2013; Mooketsi, 2000) who also found that there was inadequate student/teacher contact time to incorporate technology in mathematics teaching.

In Botswana several studies were conducted on effective use of computers. Serumola's (1992) study on the extent to which the use of computer programming in the teaching and learning of science revealed that teachers regarded introduction of computers into the learning situations as a proactive measure because computers were versatile and powerful devices in the education system. However, Serumola (1992) argued that use of computers was largely the prerogative of the individual school or teacher philosophy and the availability of the computer resources. There was need to train teachers within different departments to effectively use the computers (Serumola, 1992). Another study by Mmatli (1992) on the status of computer usage in Botswana senior secondary schools found that many schools lacked trained personnel, support facilities like printers, educational software and operated from congested rooms. In a later study on effective use of computers in the teaching and learning of mathematics at senior secondary schools in Botswana, Mooketsi (2000) found that very few teachers used computers in the teaching of mathematics and that teachers were not trained on the effective use of computers. This is critical for this study in the sense that the introduction of the computer infusion programme came long after the introduction of computers and one could only assume that the policy makers and curriculum designers had provided support in terms of training teachers to interact with the technologies. Hence, this study serves as an evaluation of the implementation of computer infusion strategy. In a very recent study on challenges of integrating ICTs into the mathematics curricula in SADC Region, Nkhwalume (2013) found that most junior secondary school mathematics teachers reported having little or no access to computers in their respective schools and computers were restricted to Computer Awareness subject. Moreover, mathematics teachers attributed their failure to integrate ICT to inadequate student/teacher contact time as they felt mathematics topics required plenty of time to integrate technology in it. The findings of this study though biased towards mathematics are paramount to this study in the sense that the subjects investigated (math, science and social studies) as shown in table 2(appendix D) have laid out objectives or competences addressing the use of technology, hence it is quite appealing for one to establish how teachers across the specified school subjects address those objectives which are mandated by the syllabus.

\subsection{Conclusion}

The extent of infusion of computers in the school curriculum need to be carefully scrutinised as inability to expose students to modern technologies at an early stage would have an adverse effect on the realisation of Botswana's vision 2016 which strives to make Botswana a regional leader in the production and dissemination of information through information technologies, computer use included (Botswana Vision 2016). Literature has shown that the infusion of computers in school subjects enables among others the manipulation of environments and events to afford multiple perspectives on complex phenomena. Also the emphasis is mainly on technological support for teachers to effectively infuse computers in their subject areas and that students taught through computers performed better than those not taught with a computer. It is anticipated that the findings of 
The Extent of Technology Infusion in the Junior Secondary School Math \& Science Curriculum: Students Views

this study would provide a basis for rigorous professional training of teachers across the subjects and also strengthen monitoring processes to ensure that the infusion of computer technology is a success.

\section{THEORETICAL FRAMEWORK}

In this study the researchers used constructivist theory to understand how technology provides new opportunities such as learning styles, student-centered instruction and promotion of higher-order thinking, the teacher's attitudes and beliefs when fully integrating technology into the classroom instructional practices. It is without doubt that constructivism is a philosophical position which holds that any so-called reality is the mental construction of those who believe they have discovered and investigated it (Saunders, 1992) and from this perspective, learning is understood to be a selfregulated process of resolving inner conflicts that become apparent through concrete experience, discussion, and reflection (Brooks \& Brooks, 1993). Constructivists believe that knowledge must be constructed by the learner and Holzer (1994) asserts that it cannot be supplied by the teacher. For example, if one considers the likes of constructivists such as Piaget, who defines knowledge as an interaction between subject and object it is imperative that learning can be nurtured. The concept of constructivism emphasises knowledge as a perpetual construction made by exchanges between thought and its object. It is not a copy of reality by the concepts of the subject that approaches the object without ever attaining it in itself. Consequently, the construction of knowledge is a dynamic process that requires the active engagement of the learners who will be responsible for ones' learning while the teacher only creates an effective learning environment, thus taking the role of a facilitator. Moreover, Gilakjani, Leong, Ishmail's (2013) view constructivism as learning that takes place in contexts, while technology refers to the designs and environments that engage learners and those recent efforts to integrate technology in the classroom have been within the context of a constructivist framework.

The researchers employed the constructivist approach to catechize the extent to which computer technology is infused across math and science subjects with the view of addressing objectives that promotes technology use. Form three students' beliefs about computer infusion and challenges experienced in the learning of math and science subject areas were analysed. It is imperative that teachers' willingness to embrace change as a major requirement for successful technology infusion has a bearing on the teacher's choice of classroom instructional practices. Similarly, technology is continuously, and rapidly, evolving, hence requires continual learning and support in terms of providing opportunities for effective technology infusion. It goes without saying that teacher support in terms of availing different forms of technology, providing students with more access to technology, could reduce the likelihood of a teacher centric learning environment whereby infusion revolves around teacher needs, not necessarily student needs.

According to the National Educational Technology Standards for Students, International Society for Technology in Education (NETSS, ISTE 2007), effective infusion of technology is achieved when students are able to select technology tools to help them obtain information in a timely manner, analyze and synthesize the information, and present it professionally. This is to say that technology should become an integral part of how the classroom functions in terms of accessibility like in any other classroom learning tools. This clearly tells us that technology has become a major component of our educational system. Supporters of technology argue that technology is often touted as the saviour of education (Collins \& Haverson, 2009).

It is on the basis of the above that constructivism becomes an instrumental tool for the investigation of the students' beliefs about the infusion of computer technology in teaching and learning of the math and science subjects. The researchers used constructivists in view of the fact that students' academic challenges are rooted in inappropriate teaching and learning strategies which tend to be teacher dominated, as opposed to learning environments that support multiple perspectives or interpretations of reality, knowledge construction, and context-rich, experience-based activities. This approach is similar to the position of the RNPE (1994), which puts emphasis on learner centered approaches. As such the apt development of increasingly powerful computer and communication systems has great implications for the constructivist approach to education. It offers a tremendous amount of information, tools for creativity and development, and various environments and forums for communication. Within a student-centered curriculum based on student performance, new technology tools provide many opportunities for students and teachers to build knowledge in an engaged setting. 
The Extent of Technology Infusion in the Junior Secondary School Math \& Science Curriculum: Students Views

\section{RESEARCH DESIGN AND METHODS}

\subsection{Research Design}

The research design for this study falls within the quantitative approaches (Cresswell, 1994; Mertens, 1998). The study employed a survey design that used students' questionnaires to collect data for quantitative purposes as it is meant to describe the "what" of a situation, and not determine cause and effect (Hale, 2011). In this study data was collected through questionnaires and open ended questions were included for the purpose of triangulation since various sources of data (qualitative and quantitative) is better than a single source as multiple sources will lead to a fuller understanding of computer infusion in this study (Bogoan and Biklen, 1998; Cohen and Manion, 1994). Triangulation in this study was intended to ensure consistency of data while experts from the department were given all the instruments to make judgments about the content. A pre-test was conducted for this study and was meant to provide valuable insights for the researcher on the suitability of the instruments and also for modifications on the instrument (Mertens, 1998). One school in Kgatleng village was used to pretest both the questionnaires.

\subsection{Selection of Participants}

The study sample was drawn from the South East Region junior secondary schools. The region comprises schools either in the rural or remote areas while South East comprises schools in Gaborone and Tlokweng which are either urban or peri-urban schools. South East region is also one of the regions in the country that has been consistently achieving the best junior certificate results (Botswana Examination Council JC results, 2010-2017). As a result 10 schools from South East region were used to draw the study sample. Form three students formed the study sample. One hundred and sixty (160) students were randomly sampled from the selected schools. The students filled in the questionnaires with the view of getting more insights on the challenges students face during infusion of computer technology in the math and science subjects.

\subsection{Sampling Procedures}

In this study non-probability sampling methods were used to select the region where participants were drawn from. This is a method of selection in which elements or participants are not chosen by chance procedures and the success depends on knowledge, expertise and judgement of the researcher. The region used in this study was chosen on the basis of convenience and economical advantage as it is within the researcher's proximity. The school participating in this research were chosen through simple random sampling whereby names of schools for a particular region were written on a piece of paper and put together in a box, from which the participating schools were picked without looking. The simple random sampling eliminates biasness and increases the equal chance of selecting participants (Wiersma and Jurs, 2005). At school level, form three students were used to fill in the questionnaires. Data was collected by the Principal Investigator with the assistance from either Head of department or senior teachers from the sampled schools.

\subsection{Data Analysis}

The researcher used quantitative methods to analyse the data. For quantitative data processes (closed ended questions), a statistical program called Statistical Package for the Social Sciences (SPSS) was used for data entry, coding and analysis of the results. Table of frequencies, bar graphs and descriptive statistics (mean, mode, standard deviation and variance) was used in the analysis. Inferential statistics i.e. a paired sample t-test, Chi-square and a one-way ANOVA were also used in the analysis.

\subsection{Ethical Considerations}

Ethical principles such as consulting all relevant stakeholders to get their consent regarding principles guiding the research and before making any observation or administering questionnaires were made (Winter, 1996). Furthermore, Creswell (1994) outlined the following safeguards which were employed in this study to protect the participants: The objectives of the research were articulated in writing so that they are clearly understood by the participants; permission to conduct research was sought from the Ministry of Basic Education (MOBE)and school authorities and participants were informed of all data collection instruments. It was be the researchers' responsibility to sustain the 
The Extent of Technology Infusion in the Junior Secondary School Math \& Science Curriculum: Students Views

principle of confidentiality of both participants and data as the data was used solely for the purpose of the study.

\section{RESUlts ANALYSIS}

This section is presented into two parts namely the demographic characteristics of the respondents and closed ended and open ended analysis. The results were computed using the statistical Package for Social Sciences (SPSS) version 23 and presented using descriptive statistics (mean, standards deviation and mode), tables of frequencies, bar charts and pie charts. To test for relationships and significance differences in the mean responses of teachers and students a Pearson Chi- Square test, Independent sample t-test and a one way ANOVA were used respectively at $\mathrm{p}$ value equal to 0.05 .

\subsection{Demographic Characteristics of Students}

This part explains the students' personal characteristics and 160 students took part in this project.

Table4.1. Gender of students

\begin{tabular}{|l|l|l|l|l|l|}
\hline \multicolumn{2}{|c|}{} & Frequency & \multicolumn{1}{|c|}{ Percent } & Valid Percent & Cumulative Percent \\
\hline \multirow{3}{*}{ Valid } & Male & 69 & 43.1 & 43.1 & 43.1 \\
\cline { 2 - 6 } & Female & 91 & 56.9 & 56.9 & 100.0 \\
\cline { 2 - 6 } & Total & 160 & 100.0 & 100.0 & \\
\hline
\end{tabular}

Table 4.1 shows the gender of student respondents. The sample consisted of 160 participants, with many more females $(n=91)$ than males $(n=69)$ which translates into $56.9 \%$ females against $43.1 \%$ males. This disproportionate in gender of students could imply that the student population in the Gaborone and Tlokweng junior secondary schools is mainly dominated by females.

\section{Closed \& open ended questions analysis}

This section presents students' responses on the following areas: beliefs about importance of computer technology infusion in learning and computer infusion as a strategy in various activities.

Figure 4.1 below presents the results from the students' survey which communicates to the level of agreement of students on importance of computer technology infusion in their learning of various school subjects.

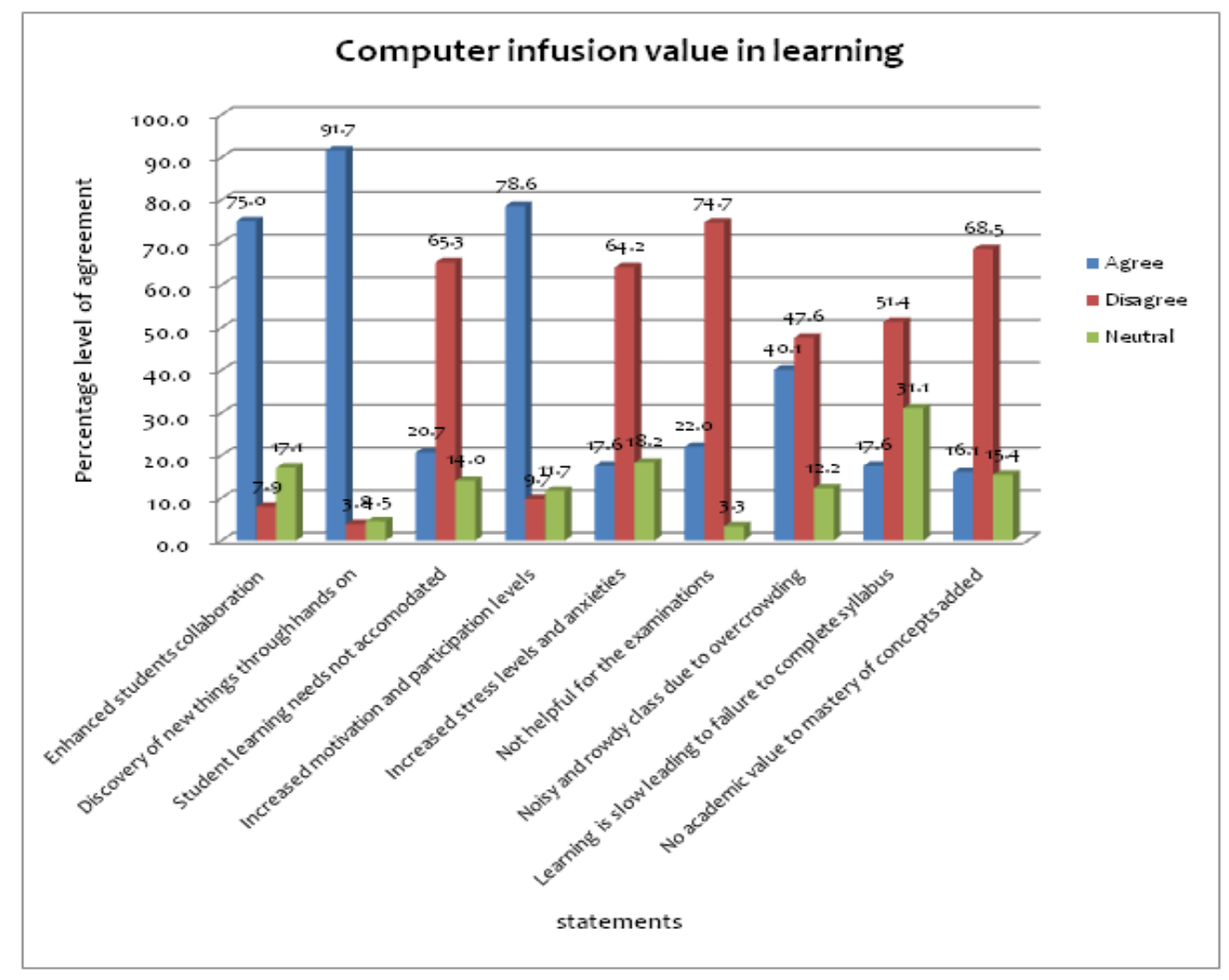

Figure4.1. Value of computer technology in learning 
The questionnaire wanted to establish the students' views about the usefulness of preparedness of computer technology in their learning by presenting statements that required students to indicate the extent of effectiveness of computers in their learning practices.

The results show that majority of the students believed computers promoted an effective classroom learning environment in terms of enhancing collaborative skills, discovery experiences and motivating them to learn. This is shown in figure 4 where $75 \%$ of the respondents indicated that computers enhanced student collaboration, $91.7 \%$ believed computers aided in discovery of new things, and $78.6 \%$ of the respondents indicated that computers increased participation and motivation levels. In support of the preceding statement, one of the respondents stated in open ended questions that "Working with a computer is fun and quite interesting and most of us especially me learn and master things better when having fun while learning. This is to say computers help us to mingle and makes the class hands-on which is good for learning, thus making the classroom to be engaging and mentally exciting." Students further reiterated on the need to build more computer labs so that they could have access to computers in all the subjects of the school curriculum. Further, one respondent said that "A computer helps us focus on the task at hand and can be an important tool for maintaining a student's interest in the topic learned". This therefore, calls for teachers to infuse computer technologies in their classroom instructional practices as a means to refresh boring lesson plans that quickly negatively affect a child's interest. In support, Lowerison, Sclater, Schmid and Abrami (2004) study on student perceived effectiveness of computer technology use in post-secondary classrooms found that students indicated that they valued the use of computer technology for learning. Furthermore, the findings showed a strong favourable response to computer use and: facilitation of learning, value-added aspects such as usefulness to other classes and/or career, learning material in a more meaningful way, and working in groups with other students. This tells us that students' readiness to use computers is guaranteed, hence it requires teachers who are knowledgeable and who acknowledges the benefits of computer use in teaching. Moreover, the results implore MOBE officials to channel financial resources to computer technology infrastructure in order to increase access and usage of computer technologies in instructional practices.

The questionnaire further wanted to establish the frequency of computer technology in various learning activities. The following statements were presented in order to get students' views on the frequency of use of computer technology in their learning processes: Frequency of computer technology for:

- Tutorial and remedial purposes

- Discovery learning and creativity purposes

- Projects for various subjects and record keeping

- Computer Assisted Learning (See figure 4.2)

Figure 4.2 presents the results from the student's survey which addresses student's views on the frequency of use of computer technology in learning through various activities intended to promote a learner centered environment.

The results show that majority of the respondents indicated that computer technology was sometimes or often used for various learning activities such as in discovery learning and creativity, computer assisted learning and in projects and record keeping. Nevertheless, there were a considerable number of students who revealed that computer technology was rarely or never used for remedial and tutorial purposes. Even though it seemed like majority of students indicated that they sometimes or often encountered computer technologies in Computer Assisted Learning, a good number indicated that computer technologies were never used for Computer Assisted Learning purposes. This is demonstrated in figure 2 where $70.4 \%$ of the respondents indicated that computer technology is sometimes or often infused for discovery or creativity purposes; $78.9 \%$ felt computers were sometimes or often infused in projects and for record keeping purposes; $59.7 \%$ of the respondents felt computers were sometimes or often used for Computer Assisted Learning purposes while $40.3 \%$ of the respondents showed that computers were rarely or never used for Computer Assisted Learning purposes. Concerning use of computer technology for tutorial and remedial purposes $58.4 \%$ indicated that they were rarely or never used for that. In support of the preceding arguments, one of the 
The Extent of Technology Infusion in the Junior Secondary School Math \& Science Curriculum: Students Views

respondents stated that "I learn new things every time we use computers in our class; hence it is important to revisit the strategy and modalities of incorporating it within the curriculum for fruitful results". Students further echoed on the need to increase the number of computers in the laboratories, provide efficient internet services and train teachers on the effective use of computer technology in teaching and learning processes. This finding corroborates Hartley and Treagust's (2014) study on learner perceptions of the introduction of Computer Assisted Learning in their mathematics classrooms who found that Learners indicated that they considered application of computers as a positive step as it (1) increased their involvement in the mathematics classroom, (2) gave them more exercises in problem solving in mathematics, and (3) provided them with the opportunity to assess their own learning. This is a clear indication that students value the computer infusion, thus prompting schools to avail more computers in order to allow learners to work individually and thereby providing them with more opportunities to be able to spend more time using the computers. Consequently, these results call upon policy makers, In-service officers, teachers/educators and curriculum developers to see the need to provide an enabling learning environment that subscribes to the technology driven curriculum. This indeed is a step forward as students seem to have embraced the use of technology in their learning. There is therefore, a need for teachers to eliminate the perceived notion that "the teacher knows it all", whereby classrooms are still dominated by traditional teaching methods such as lectures and discussions, and move teaching and learning from the idea that the student is a passive recipient of information and moving toward the idea that the learning process is active and learnercentered. An equally significant aspect drawn from the student findings where majority indicated that computers were rarely or never used for remedial and tutorial purposes needs to be seriously looked into as it is evident that students are not given adequate opportunity to use computers to extend their knowledge subject base. Schacter and Fagnago (1999) reiterated the preceding argument as he stated that a common criticism of computer infusion is that computers are most commonly used for drilland-practice exercises that typically do not promote deep and meaningful learning. There is need for teachers to consider why they are using technology in their classes and help students appreciate the benefits which are undoubtedly outclassing the negatives. According to Grasha and Yangarber-Hicks (2000) and McCombs (2000), many teachers appear to use technology simply to "try it out.", calling for appropriate use of computer technology for effectiveness. It is my belief that computer technology can improve teaching and learning practices but as alluded by Ehrmann (1995) it is important to take cognisance of how and what students are being taught through computer technologies.

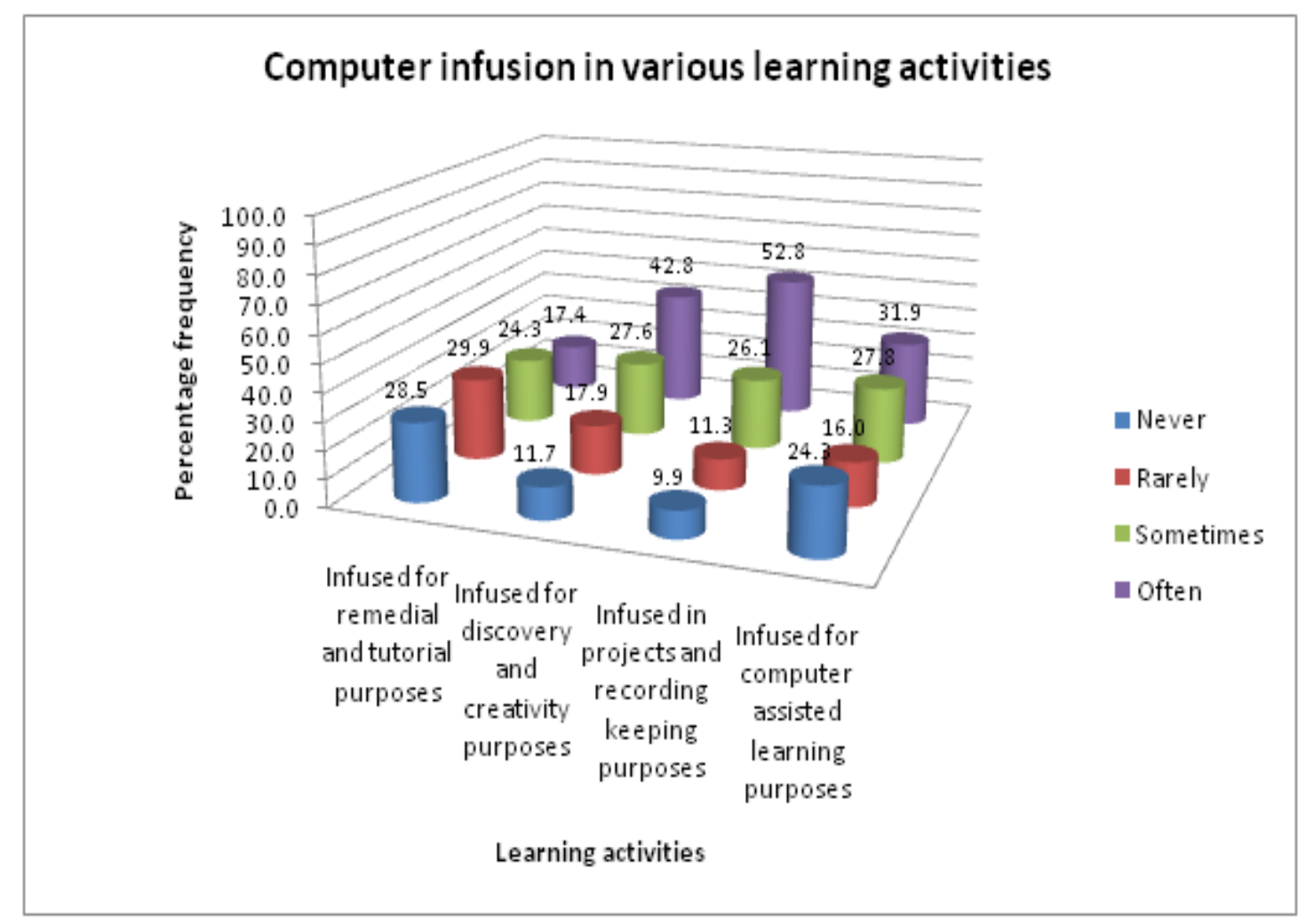

Figure4.2. Computer use in various learning activities 
The Extent of Technology Infusion in the Junior Secondary School Math \& Science Curriculum: Students Views

Table 4.2(a). Percentage students' gender beliefs about computer infusion in their learning

\begin{tabular}{|l|l|l|l|l|l|l|l|}
\hline & \multicolumn{1}{|c|}{ Statement } & \multicolumn{3}{c|}{ Male } & \multicolumn{3}{c|}{ Female } \\
\hline $\begin{array}{l}\text { Sr. } \\
\text { No }\end{array}$ & \multicolumn{1}{|c|}{$\begin{array}{c}\text { Agree } \\
(\%)\end{array}$} & $\begin{array}{c}\text { Disagree } \\
(\%)\end{array}$ & $\begin{array}{c}\text { Neutral } \\
(\%)\end{array}$ & $\begin{array}{c}\text { Agree } \\
(\%)\end{array}$ & $\begin{array}{c}\text { Disagree } \\
(\%)\end{array}$ & Neutral \\
\hline 1 & $\begin{array}{l}\text { Computers enhance collaboration } \\
\text { among students }\end{array}$ & 69.7 & 12.1 & 18.2 & 76 & 4.7 & 16.3 \\
\hline 2 & $\begin{array}{l}\text { Computers provide opportunity to } \\
\text { discover new things through } \\
\text { hands on experience }\end{array}$ & 89.5 & 4.5 & 6 & 93.2 & 3.3 & 3.4 \\
\hline 3 & $\begin{array}{l}\text { Computer does not accommodate } \\
\text { student learning needs }\end{array}$ & 18.8 & 68.8 & 12.5 & 22.1 & 62.8 & 15.1 \\
\hline 4 & $\begin{array}{l}\text { Computer increase students' } \\
\text { motivation and participation levels }\end{array}$ & 75.4 & 12.3 & 12.3 & 80.9 & 7.8 & 11.2 \\
\hline 5 & $\begin{array}{l}\text { Computer increase students' } \\
\text { stress levels and anxieties }\end{array}$ & 20 & 55 & 25 & 15.9 & 70.5 & 13.6 \\
\hline 6 & $\begin{array}{l}\text { Computer increase students' } \\
\text { motivation and participation levels }\end{array}$ & 23.8 & 73 & 3.2 & 20.6 & 75.8 & 34 \\
\hline 7 & $\begin{array}{l}\text { Computer makes classroom noisy } \\
\text { and rowdy }\end{array}$ & 42.4 & 47.5 & 10.2 & 38.6 & 47.8 & 13.6 \\
\hline 8 & $\begin{array}{l}\text { Computer use leads to non- } \\
\text { completion of syllabus }\end{array}$ & 11.9 & 49.1 & 39 & 21.4 & 52.8 & 25.8 \\
\hline 9 & $\begin{array}{l}\text { Computer does not add academic } \\
\text { value to mastery of concepts }\end{array}$ & 17 & 66.1 & 16.9 & 15.6 & 70 & 14.4 \\
\hline
\end{tabular}

Table 4.2(b). Frequency of computer technology in various learning activities by gender

\begin{tabular}{|l|l|l|l|l|l|}
\hline & & \multicolumn{2}{|c|}{ Male } & \multicolumn{2}{c|}{ Female } \\
\hline $\begin{array}{c}\text { Sr. } \\
\text { No. }\end{array}$ & \multicolumn{1}{|c|}{ Statement } & $\begin{array}{c}\text { Rarely or } \\
\text { Never (\%) }\end{array}$ & $\begin{array}{c}\text { Sometimes or } \\
\text { Often (\%) }\end{array}$ & $\begin{array}{c}\text { Rarely or } \\
\text { Never (\%) }\end{array}$ & $\begin{array}{c}\text { Sometimes } \\
\text { or Often (\%) }\end{array}$ \\
\hline 10 & $\begin{array}{l}\text { computers infused for remedial and } \\
\text { tutorial purposes }\end{array}$ & 59.3 & 40.7 & 42.4 & 57.6 \\
\hline 11 & $\begin{array}{l}\text { computers infused for discovery and } \\
\text { creativity purposes }\end{array}$ & 31.1 & 69 & 28.7 & 71.3 \\
\hline 12 & $\begin{array}{l}\text { computers infused for projects and } \\
\text { recording keeping purposes }\end{array}$ & 28 & 71.9 & 16.5 & 83.6 \\
\hline 13 & $\begin{array}{l}\text { computers infused for Assisted } \\
\text { Learning purposes }\end{array}$ & 45.6 & 54.4 & 36.7 & 63.2 \\
\hline
\end{tabular}

Table 4.2(c). Chi-square tests for students' gender beliefs about computer infusion and frequency of its use in various learning activities.

\begin{tabular}{|l|l|l|l|l|l|l|}
\hline & \multicolumn{2}{|c|}{ Statement dests } & \multicolumn{2}{c|}{ Symmetric measures } \\
\hline No. & \multicolumn{1}{|c|}{$\begin{array}{c}\text { Pearson } \\
\text { Chi-square }\end{array}$} & $\begin{array}{c}\text { Asymp. Sig. } \\
\text { (2 sided) }\end{array}$ & \multicolumn{2}{c|}{$\begin{array}{c}\text { Nominal by } \\
\text { nominal Phi value }\end{array}$} & $\begin{array}{c}\text { Approx. } \\
\text { Sig. }\end{array}$ \\
\hline 1 & $\begin{array}{l}\text { Computers enhance collaboration } \\
\text { among students }\end{array}$ & 3.374 & 4 & 0.497 & 0.149 & 0.497 \\
\hline 2 & $\begin{array}{l}\text { Computers provide opportunity to } \\
\text { discover new things through hands on } \\
\text { experience }\end{array}$ & 6.125 & 4 & 0.190 & 0.198 & 0.190 \\
\hline 3 & $\begin{array}{l}\text { Computer does not accommodate } \\
\text { student learning needs }\end{array}$ & 3.411 & 4 & 0.491 & 0.151 & 0.491 \\
\hline 4 & $\begin{array}{l}\text { Computer increase students' } \\
\text { motivation and participation levels }\end{array}$ & 15.136 & 4 & 0.004 & 0.314 & 0.004 \\
\hline 5 & $\begin{array}{l}\text { Computer increase students stress } \\
\text { levels and anxieties }\end{array}$ & 4.306 & 4 & 0.366 & 0.171 & 0.366 \\
\hline 6 & $\begin{array}{l}\text { Computer increase students } \\
\text { motivation and participation levels }\end{array}$ & 0.996 & 4 & 0.910 & 0.081 & 0.910 \\
\hline 7 & $\begin{array}{l}\text { Computer makes classroom noisy and } \\
\text { rowdy }\end{array}$ & 9.458 & 4 & 0.051 & 0.254 & 0.051 \\
\hline 8 & $\begin{array}{l}\text { Computer use leads to non- } \\
\text { completion of syllabus }\end{array}$ & 6.965 & 4 & 0.138 & 0.217 & 0.138 \\
\hline
\end{tabular}


The Extent of Technology Infusion in the Junior Secondary School Math \& Science Curriculum: Students Views

\begin{tabular}{|l|l|l|l|l|l|l|}
\hline 9 & $\begin{array}{l}\text { Computer does not add academic } \\
\text { value to mastery of concepts }\end{array}$ & 7.381 & 4 & 0.117 & 0.223 & 0.117 \\
\hline 10 & $\begin{array}{l}\text { computers infused for remedial and } \\
\text { tutorial purposes }\end{array}$ & 1.641 & 4 & 0.801 & 0.107 & 0.801 \\
\hline 11 & $\begin{array}{l}\text { computers infused for discovery and } \\
\text { creativity purposes }\end{array}$ & 0.945 & 4 & 0.918 & 0.081 & 0.918 \\
\hline 12 & $\begin{array}{l}\text { computers infused for projects and } \\
\text { recording keeping purposes }\end{array}$ & 5.173 & 4 & 0.270 & 0.191 & 0.270 \\
\hline 13 & $\begin{array}{l}\text { computers infused for Assisted } \\
\text { Learning purposes }\end{array}$ & 2.298 & 4 & 0.681 & 0.126 & 0.681 \\
\hline
\end{tabular}

The results indicate that gender did not influence students' beliefs about computer technology infusion in their learning and the frequency it is used in various learning activities. This is shown by table 4.2(a) and 4.2(b) where majority of each gender indicated a positive view about computer technology infusion and frequency of its use in various learning activities. Table 4.2(b) further reveals that a high percentage of either gender indicated that they sometimes or often infused computer technology in various learning activities such as projects and record keeping, discovery learning \& creativity, Computer Assisted Learning with the exception of tutorials \& remediation whereby 59.3\% of male respondents indicated that they never or rarely infused computer technology in remedial and tutorial activities. A chi-square test of independence was performed to examine the relation between gender and students' belief about the frequency of computer technology infusion in various learning activities. The relation between these variables was not significant; hence the level of association between gender and the responses to various statements showed that gender and students' beliefs and infusion of computer technology in various activities were independent. In other words there is no significant difference between gender response on their beliefs and frequency and extent of computer technology use in various learning activities. However, there was a significance difference in students' gender belief about the level of agreement on whether computers increase students' motivation and participation levels or not. In support of the results the Pearson Chi-square results (figure 4.2(c)) show that for all statements except one on computers increase students' motivation and participation levels, $\mathrm{p}>0.05$ and the $\mathrm{P}$ values for the symmetric measures are all far greater than the critical value of 0.05 , hence depicting a weak positive relation between the variables (gender and students' beliefs, the extent and frequency of computer technology use in students' various learning activities). As indicated earlier, the relation between student gender beliefs about whether computers increased students' motivation and participation levels or not in their learning was significant, $\chi^{2}(4, \mathrm{~N}$ $=144)=15.136, \mathrm{p}(0.004)<0.05$. This suggests that female students were more likely to believe that use of computer technologies in the classroom learning was more likely to increase students' motivation and participation levels. (Percentage of agreement level is $80.9 \%$ as compared to $75.4 \%$ for their male counterparts. This upholds Akbulut, Odabasi, and Kuzu's (2011) study findings on preservice teachers regarding the evaluations on Information and Communication Technologies (ICT) indicators at Turkish education faculties, where it was found that female evaluations regarding indicators for ICT were more positive in terms of Learning Communities, which entails a group of people who share common academic goals and attitudes, who meet semi-regularly to collaborate on classwork. This clearly suggests that females are more likely to embrace computer technology with the view to enhance or strengthen their collaborative skills, an attribute essential for effective learning practices. It is therefore, imperious that policy implementers evaluate gender learning issues as a way of drawing strategies intended to enhance a computer technology environment that is free from gender differences, as the infusion of computers in learning is a strategy that promotes learning of higher order skills irrespective of gender.

Table 4.2(d). A summary of results on students' beliefs about frequency of computer use in learning by gender using a one-way ANOVA

\begin{tabular}{|l|l|l|l|l|r|}
\hline & \multicolumn{1}{|c|}{ DF } & \multicolumn{1}{|c|}{ Sum of Squares } & \multicolumn{1}{c|}{ Mean Squares } & F & Sig. \\
\hline Q1. Between Groups & 1 & 2.125 & 2.125 & 2.065 & 0.153 \\
Within Groups & 150 & 154.342 & 1.029 & & \\
\hline Total & 151 & 156.467 & & 2.677 & 0.104 \\
\hline Q2. Between Groups & 1 & 1.828 & 1.828 & & \\
Within Groups & 154 & 105.146 & & & \\
\hline Total & 155 & 106.974 & & & \\
\hline
\end{tabular}

International Journal of Humanities Social Sciences and Education (IJHSSE) 
The Extent of Technology Infusion in the Junior Secondary School Math \& Science Curriculum: Students Views

\begin{tabular}{|c|c|c|c|c|c|}
\hline $\begin{array}{l}\text { Q3. Between Groups } \\
\text { Within Groups }\end{array}$ & $\begin{array}{l}1 \\
148\end{array}$ & $\begin{array}{l}.011 \\
233.883\end{array}$ & $\begin{array}{l}.011 \\
1.580\end{array}$ & .007 & 0.935 \\
\hline Total & 149 & 233.893 & & & \\
\hline $\begin{array}{l}\text { Q4. Between Groups } \\
\text { Within Groups }\end{array}$ & $\begin{array}{l}1 \\
152 \\
\end{array}$ & $\begin{array}{l}2.187 \\
164.877 \\
\end{array}$ & $\begin{array}{l}2.187 \\
1.085\end{array}$ & 2.017 & 0.158 \\
\hline Total & 153 & 167.065 & & & \\
\hline $\begin{array}{l}\text { Q5. Between Groups } \\
\text { Within Groups }\end{array}$ & $\begin{array}{l}1 \\
146 \\
\end{array}$ & $\begin{array}{l}3.243 \\
208.074\end{array}$ & $\begin{array}{l}3.243 \\
1.425 \\
\end{array}$ & 2.276 & 0.134 \\
\hline Total & 147 & 211.318 & & & \\
\hline $\begin{array}{l}\text { Q6. Between Groups } \\
\text { Within Groups }\end{array}$ & $\begin{array}{l}1 \\
48\end{array}$ & $\begin{array}{l}0.487 \\
287.973\end{array}$ & $\begin{array}{l}0.487 \\
1.946\end{array}$ & 0.250 & 0.617 \\
\hline Total & 49 & 288.460 & & & \\
\hline $\begin{array}{l}\text { Q7. Between Groups } \\
\text { Within Groups }\end{array}$ & $\begin{array}{l}1 \\
45 \\
\end{array}$ & $\begin{array}{l}1.075 \\
326.965\end{array}$ & $\begin{array}{l}1.075 \\
2.255\end{array}$ & 0.477 & 0.491 \\
\hline Total & 146 & 328.041 & & & \\
\hline $\begin{array}{l}\text { Q8. Between Groups } \\
\text { Within Groups }\end{array}$ & $\begin{array}{l}1 \\
146 \\
\end{array}$ & $\begin{array}{l}0.048 \\
196.891 \\
\end{array}$ & $\begin{array}{l}0.048 \\
1.349 \\
\end{array}$ & 0.036 & 0.851 \\
\hline Total & 147 & 196.939 & & & \\
\hline $\begin{array}{l}\text { Q9. Between Groups } \\
\text { Within Groups }\end{array}$ & $\begin{array}{l}1 \\
147 \\
\end{array}$ & $\begin{array}{l}1.674 \\
210.876\end{array}$ & $\begin{array}{l}1.674 \\
1.435\end{array}$ & 1.167 & 0.282 \\
\hline Total & 148 & 212.550 & & & \\
\hline $\begin{array}{c}\text { Q10. Between Groups } \\
\text { Within Groups }\end{array}$ & $\begin{array}{l}1 \\
142 \\
\end{array}$ & $\begin{array}{l}0.000 \\
214.222 \\
\end{array}$ & $\begin{array}{l}0.000 \\
1.509 \\
\end{array}$ & 0.000 & 0.994 \\
\hline Total & 143 & 214.222 & & & \\
\hline $\begin{array}{l}\text { Q11.Between Groups } \\
\text { Within Groups }\end{array}$ & $\begin{array}{l}1 \\
143\end{array}$ & $\begin{array}{l}0.115 \\
246.437\end{array}$ & $\begin{array}{l}0.115 \\
1.723\end{array}$ & 0.067 & 0.797 \\
\hline Total & 144 & 246.552 & & & \\
\hline $\begin{array}{c}\text { Q12.Between Groups } \\
\text { Within Groups }\end{array}$ & $\begin{array}{l}1 \\
140 \\
\end{array}$ & $\begin{array}{l}6.180 \\
253.735\end{array}$ & $\begin{array}{l}6.180 \\
1.812 \\
\end{array}$ & 3.410 & 0.067 \\
\hline Total & 141 & 259.915 & & & \\
\hline $\begin{array}{c}\text { Q13.Between Groups } \\
\text { Within Groups }\end{array}$ & $\begin{array}{l}1 \\
142 \\
\end{array}$ & $\begin{array}{l}0.445 \\
260.110 \\
\end{array}$ & $\begin{array}{l}0.445 \\
1.832 \\
\end{array}$ & 0.243 & 0.623 \\
\hline Total & 143 & 260.556 & & & \\
\hline
\end{tabular}

The results from table 4.2(d) show that there was no statistically significant difference between groups as determined by a one-way ANOVA where the $\mathrm{p}$ values were all greater than 0.05 . Furthermore, table 4.2(e) shown below, reveals that the test for homogeneity of variances is not significant for most of the statements (i.e., the $\mathrm{p}$ value ranged from 0.088 to 0.785 , which is greater than 0.05 ). This indicates that the homogeneity of variances assumption is met for all the statements except for statement which required students to indicate whether they believed learning with computers was slow, thus leading to failure to complete syllabus or not. As evidenced by a $p$ value of 0.010 which is less than 0.05 , it is indicative that the test of homogeneity of variance is significant and the assumption has not been met. This tells us that there is a variation in gender response to the statement and furthermore the percentage response for males who agreed that learning with computers led to non-completion of syllabus was $11.9 \%$ compared to $21.4 \%$ and $39 \%$ of males were undecided while $25.8 \%$ of females were, thus possibly leading to variation in the gender response.

Table 4.2(e). Test of homogeneity of variances in students gender responses

\begin{tabular}{|c|c|c|c|c|c|c|c|c|c|c|}
\hline & \multicolumn{2}{|c|}{$\begin{array}{c}\text { Levene's Test for } \\
\text { Equality of Variances }\end{array}$} & \multicolumn{7}{|c|}{ t-test for Equality of Means } \\
\hline & & \multirow[t]{3}{*}{ F } & \multirow{3}{*}{ Sig. } & & \multirow[t]{3}{*}{ df } & \multicolumn{2}{|c|}{ Sig. (2-Mean } & \multirow{2}{*}{\multicolumn{3}{|c|}{$\begin{array}{l}\text { Std. Error } 95 \% \text { Confidence } \\
\text { Difference Interval of the } \\
\text { Difference }\end{array}$}} \\
\hline & & & & & & tailed) & Difference & & & \\
\hline & & & & & & & & & Lower & Upper \\
\hline 1 & $\begin{array}{l}\text { Equal variances } \\
\text { assumed }\end{array}$ & 2.943 & 0.088 & $\begin{array}{l}- \\
1.437 \\
\end{array}$ & 150 & 0.153 & $0-.239$ & 0.166 & -0.567 & 0.089 \\
\hline & $\begin{array}{l}\text { Equal variances } \\
\text { not assumed }\end{array}$ & & & $\begin{array}{l}- \\
1.394 \\
\end{array}$ & 121.358 & 0.166 & -0.239 & 0.171 & -0.577 & 0.100 \\
\hline 2 & Equal variances & 1.341 & .249 & - & 154 & 0.104 & -0.219 & 0.134 & -0.483 & 0.045 \\
\hline
\end{tabular}


The Extent of Technology Infusion in the Junior Secondary School Math \& Science Curriculum: Students Views

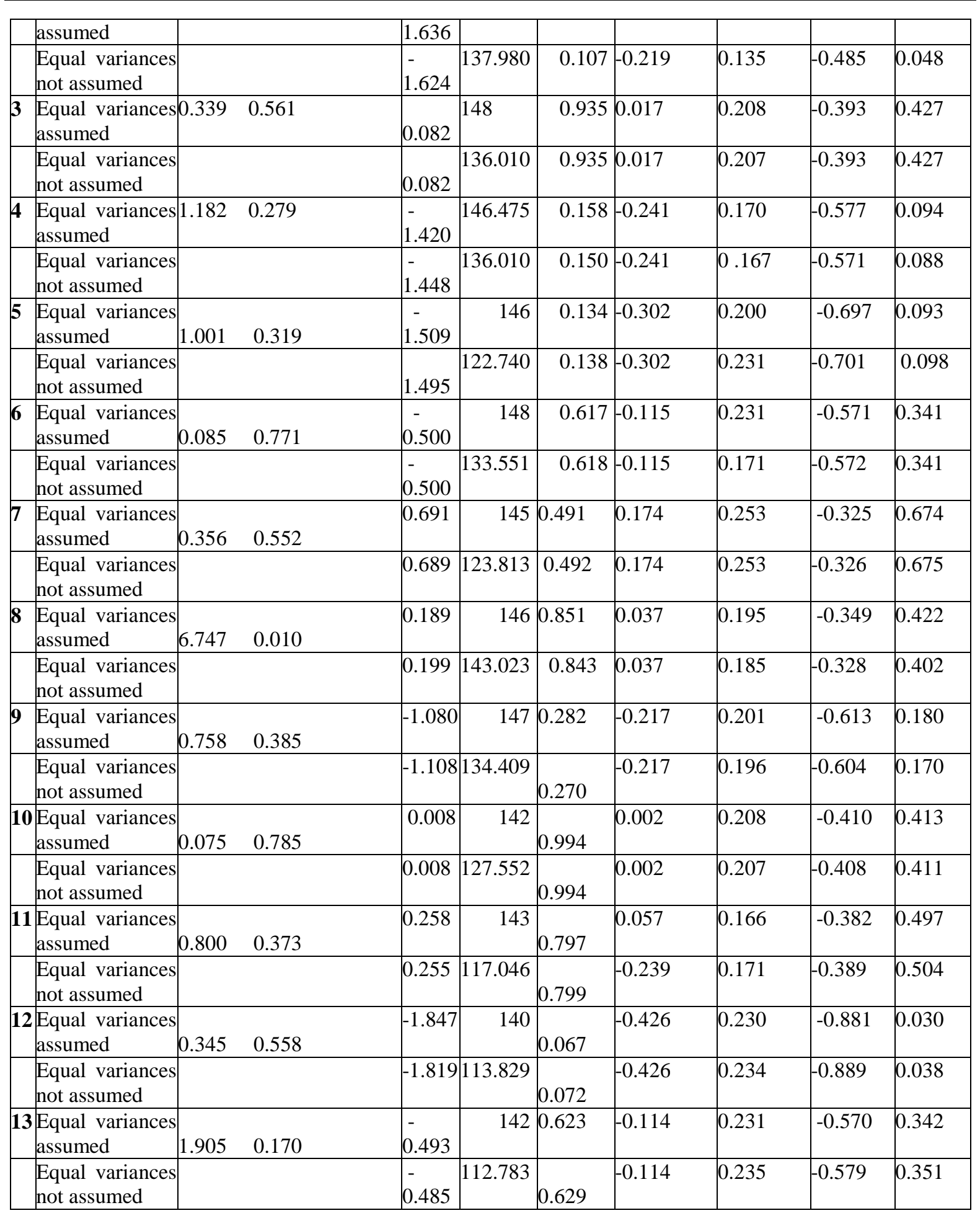

\section{SUMMARY OF FINDINGS}

This section summarises the findings according to the following research questions:

Q1.What are students' beliefs about computer infusion in the classroom instructional practices?

The findings from this study revealed most of the students felt computers promoted an effective classroom learning environment in terms of enhancing collaborative skills, discovery experiences and motivating them to learn better. They further indicated that learning through computer technology could enhance their creativity, a skill essential for meaningful learning. It also revealed that gender was not a factor as all students possessed a positive view on the importance of computer technology infusion in their learning. Different from the preceding argument, most of the students also felt that they were not accorded enough computer technology practice and experience as they felt teachers did 
not accord them with opportunities to use computers through remediation and or tutorial sessions. They felt computers were useful tools to empower them with relevant technological skills and adequate experience that could facilitate their learning of concepts with understanding.

Q2. What challenges do students face during learning through computer infusion approach?

The findings revealed that students felt that they had limited access to computers due to their shortage and that the computer laboratories were not enough to accommodate their technology needs. Furthermore, they felt that there was inadequate computer equipment in terms of hardware and software, a situation that adversely impacted their learning environment across the school curriculum. At the same time, limited access to computers led to non-exposure to tutorials and remediation activities through computers. An equally significant aspect of challenges raised by students is that they felt that available computers were not enough to meet their needs and also internet services were not efficient as it was slow and unreliable for their academic research purposes. The findings further reiterated on the need to train teachers so that they are empowered with computer skills, as they felt they were not benefiting as minimal computer skill was proffered to them.

Q3. What recommendations do teachers and students make for effective implementation of computer infusion in the classroom instruction?

The findings revealed the following recommendations made by students as strategies intended to improve teaching and learning through computers:

Students deplored lack of time as they felt the current slot reserved for computers was inadequate to proffer them an opportunity to learn higher order skills with the computer. They further stressed that computers should be integrated in different subjects instead of just in computer awareness as is the case. For this reason, students pointed out ion the need to have an examinable computer studies subject introduced as a way to sensitize schools on the importance of computers in teaching, which seem not to be the case at the present moment. Another significant point raised by students is on the issue of building more computer labs and providing enough computers to eliminate the existing overcrowding which is counterproductive in mastery of computer skills.

\section{CONCLusions}

This study found that teachers upheld the benefits of computer technology infusion, including among others their potential to develop cooperative skills which are instrumental towards students motivation. However, teachers also felt computers are likely to take their pride and role as teachers. Teachers also decried that computers were an extra workload suggesting the likelihood of teachers resisting change to incorporate technology in their teaching. Similarly students like their teachers felt computers enhance their collaborative and discovery skills leading to a motivated learning environment. However, students felt teachers did not expose them adequately to computer technologies, a situation that could hamper technological developments in their lives.

The findings uncovered challenges faced by both teachers and students during computer technology infusion. It revealed that teachers had inadequate professional experience and in-service training on computer technology, a situation that made infusion far from reality. Students decried limited access to computers as it was revealed that computers were not enough to serve every student adequately. It also revealed that internet services were not efficient as it did not benefit students in their learning processes.

\section{RECOMMENDATIONS}

With regard to the research findings and conclusions drawn from the study, certain areas need to be re-considered for they significantly affect the effective infusion of computer technology in classroom instruction. The researchers have categorised recommendations by stakeholders.

\section{Present AND Future Teachers}

Teachers should learn and embrace computer technology instruction as an alternative classroom instructional practice so as to meet the digital native students existing in the classrooms of today. This would enhance teachers' ability to explore the relationship between pedagogy and technology. If you walk into any of the sampled schools, you find at least twenty computers, but the question is how there are used by the teachers. More and more studies show that technology infusion in the curriculum 
improves students' learning processes and outcomes (Okojie, Olinzock \& Okojie-Boulder, 2006; Moeller \& Reitzes, 2011; Marwan, 2008). The findings have revealed a positive view from both students and teachers as they indicated that technology has revolutionized the way people think, work, and play. Technology, when integrated into the curriculum, revolutionizes the learning process. Furthermore, the findings have revealed that teachers who recognize computers as problem-solving tools change the way they teach. As a consequence, they move from a behavioural approach to a more constructivist approach, whereby students are engaged in their learning using these powerful tools, and can become creators and critics instead of just consumers or passive learners. It is therefore, imperative that teachers should consider computer technology used for teaching and learning as an integral part of instruction and not as an object limited to itself. Accordingly, as teachers view technology infusion from a wide perspective they will be provided with necessary foundations to implement technology into the classroom more successfully.

\section{SCHOOL HeAdS AND SENIOR TEACHER ACADEMICS}

The school management should play a leading role in ensuring the effective infusion of computer technology in the school curriculum and this could be achieved through developing infusion strategies and conducting planned monitoring and evaluation of the same. Furthermore, teachers should be supported in terms of proper planning and instructional support to effectively integrate computers in their classroom teaching. The school management should ensure that there is adequate funding for hardware and software, internet connectivity and computer-related technical problems. Often the issue for a school is not the number of computers it has, but what teachers are able to do with them. Bennett (1996) shared similar views when he said that teachers' initial decision to incorporate computers into their instruction has a prerequisite: they must be taught to use computers. Moreover, Noeth and Volkov (2004) emphasises that the existence of a particular technology does not dictate the manner in which it will be used. The correct and relevant software and connections to the Internet should be ensured by the school management or administration and as Bennett points out that the need for training of teachers creates an immediate and major obstacle to full use of computers in today's schools because hundreds of thousands of teachers lack the needed expertise. It is therefore upon the school managers that they collectively lobby higher levels in the Regional Education office for more resources in terms of hardware, and related software. There should also ensure a complete and reliable internet services as this falls within their jurisdiction as school managers. Going back to the data, as one math teacher stressed, "The school does not have enough computers and those available only 5 of them are functional and I also do not have enough experience. It would be great if teachers are first given in-service training on how they can infuse computers in different subjects of learning. I believe then computer technology would be best infused into the curriculum."

\section{FUTURE RESEARCH}

There should a sampling from a much broader spectrum of students and teachers who are involved with computer technology infusion in the secondary education level. There is also a need to survey perceptions of school management on the computer infusion programme in their respective schools. In pursuit of better strategies to ensure effective computer technology infusion, the priority levels of computer technology in the secondary school curriculum needs to be established and to what level of importance it is to train teachers in preparation for the infusion of computer technology strategy.

\section{REFERENCES}

[1] Ahmad, K, Corbett, G; Sussex, R, and Rogers, M. (1985). Computers, Language Learning, and Language Teaching. United kingdom: Cambridge University Press.

[2] Akbulut, Y., Odabasi, H.F., \& Kuzu, A. (2011).Perceptions of Pre-service Teachers regarding the Infusion of Information and Communication Technologies in Turkish Education Faculties. The Turkish Online Journal of Educational Technology, volume 10(3), pp. 175-184. Retrieved on July 27, 2017 from http:// files.eric.ed.gov/fulltext/EJ944961.pdf

[3] Balacheff, N. and Kaput, J.J. (1996). Computer- Based Learning Environments in Mathematics. In A.J. Bishop et al. (Eds), International Handbook of Mathematics Education, 435-468.London: Kluwer Academic Publishers

[4] Bennett, F. (1996). Why Computers are ineffective today. First Monday Peer Reviewed Journal on the Internet. Retrieve on August 04, 2017 from http://firstmonday.org/ojs/index.php/fm/article/view/502/423 
The Extent of Technology Infusion in the Junior Secondary School Math \& Science Curriculum: Students Views

[5] Benwell, G.A. (1986). Integrating the computer into language course. In C.J. Brumfit, M. Philips and P. Skehan (Eds.), Computers in English Language Teaching. A view from the classroom. New York: Pergamon Press.

[6] Bogoan, R.C. \& Biklen, S.K. (1998). Qualitative Research for Education: An Introduction to theory and methods ( $3^{\text {rd }}$ Ed.). Allyn \& Bacon: Boston.

[7] Borris, H. (2004). Teachers Instructional Beliefs about integrating educational Technology. Retrieved 09 March, 2017 from: http://www.calculators researchlteachers belief calculators.htm

[8] Botswana (1994). Revised National Policy on Education. Gaborone: Government Printers.

[9] Botswana Examination Council (2010-2017). Summary of Junior Certificate Results. Retrieved on 10 September 2017 from: http://www.bec.bw

[10] Botswana Government (1997). Botswana Vision 2016. Government Printers.

[11] Botswana Three Year Junior Certificate Curriculum Blueprint (2008). Three year J.C syllabus 2008. Curriculum Division.

[12] Botswana Three Year Junior Certificate Curriculum Blueprint (2010). Three year J.C syllabus 2010. Curriculum Division.

[13] Bozkurt, A(2011). A classroom observation - Based Evaluation of Elementary Teachers' use of Technology in the classroom in Turkey. Educational Research \& Reviews, 6(4), 367-373. Retrieved on 22 August 2017, from: http:/ehis.ebscohost.com/eds .

[14] Brooks, J.G., \& Brooks, M.G.(1993). "The case for constructivist classrooms," Alexandria, VA.: Association for Supervision and Curriculum Development.

[15] Cohen, L. \& Manion, L. (1994). Research methods in Education (4 ${ }^{\text {th }}$ ed.). Routledge: London.

[16] Collins, A., \& Halverson, R. (2009). Rethinking education in the age of technology: The digital revolution and schooling in America. New York, NY: Teachers College Press.

[17] Confrey,J.(1990). "What constructivism implies for teaching," In Constructivist views of mathematics.

[18] Cook, V.J. (1985). Bridging the gap between computers and language teaching. Hammorweg 6: Pergamon Press.

[19] Cornu, B(1995). New Technologies: infusion into education. In D. Watson and D. Tinsley (Eds.). Integrating Information Technology into Education (pp.3-11). London: Chapman \& Hall.

[20] Creswell, J. W. (1994). Research Design: Qualitative \& Quantitative Approaches. Sage Publications: London

[21] Dagiene, V, Dzemyda, G and Sapagovas, M. (2006). Evolution of the cultural based paradigm for informatics Education in secondary schools. In R.T. Mittermeir (Ed.), Informatics Education- The Bridge between using and understanding Computers. Berlin: Springer Verlay.

[22] DeHoyos, M \& Anne Bannes, S. (2012). Analysing Data. Retrieved on 20 September, 2017 from: http://www.warwick.ac.uk/fac/cross.../analysing_interview_data_1_-_w6.pdf

[23] Du Plessis, A. \& Webb, P. (2012).Teachers' Perceptions about Their Own and Their Schools' Readiness for Computer Implementation: A South African Case Study. The Turkish Online Journal of Educational Technology, Vol 11(3), pp.1-14. Retrieved on July 28, 2017 fromhttp://files.eric.ed.gov/fulltext/EJ98922 3.pdf.

[24] Ehrmann, S. C. (1995). Asking the right question: what does research tell us about technology and higher learning?. Higher Learning, 27(2), 20-27, Available online at: http://www.learner.org/edtech/rscheval/righ tquestion.html.

[25] Eristi, S. D., Kurt, A. A., \& Dindar, M. (2012). Teachers' Views about Effective Use of Technology in Classrooms. Online Submission, 3(2), 30-41. Retrieved on July 28, 2017 from https://files.eric.ed.gov/fulltext/ED537802.pdf.

[26] Forcier, R.C. (1999). The Computer as an Educational Tool: Productivity and Problem solving ( $2^{\text {nd }}$ ed.). Merril: New Jersey.

[27] Gall, M. D, Borg, W.R, Gall, J.P. (1996). Educational Research: an Introduction. Toronto: Longman Publishers.

[28] Garegae, K.G. (2003). The Effect of Technologyon the Mathematics Curriculum: Examining the Trilogy.In J. Matsoga et al (Eds.). .) Mosenodi,Journal of the Botswana Educational Research Association 17(1). 27-38. Gaborone: BERA.

[29] Gilakjani, A. P., Leong, L. M. \& Ismail, H.N. (2013). Teachers' Use of Technology and Constructivism. International Journal of Modern Education and Computer Science, 4, pp. 49-63. Online May 2017 in MECS (http://www.mecs-press.org/) DOI: 10.5815/ijmecs.

[30] Grasha, A. F., \& Yangarber-Hicks, N. (2000). Integrating teaching styles and learning styles with instructional technology. College Teaching, 48, 2-10. 
[31] Hale, J. (2011). The 3 Basic Types of Descriptive Research Methods. Psych Central. Retrieved on 10 February, 2017 from: http//psychcentral.com /blog/archives /2011/09/27/the 3- basic- types-of- descriptive - research- methods/

[32] Hartley, M. S.\& Treagust, D.F.(2014). Learner Perceptions of the Introduction of Computer- Assisted Learning in Mathematics at a Peri-Urban Schoolin South Africa. Learning Environments Research, Vol 17(1), pp. 95-111.Retrieved on July 23, 2017 from http://eds.b.ebscohost.com/eds/ -

[33] Holzer,S.(1994). "From Constructivism to Active Learning," The Innovator, no.2. Johnson, D, Maddux, C.D and Liu, L. (2000). Infusion of Technology into the classroom: Case studies. New York: The Haworth Press, Inc.

[34] Kadisa, C. (2009). The use of computers and extent of computer infusion in the learning of preschool children in Botswana. Unpublished M.Ed Special project. University of Botswana, Gaborone, Botswana.

[35] Kaino, L.M. \& Salani, E. (2004). Students' gender attitudes towards the use of calculators in mathematics instruction. Retrieved on 10 February, 2017, from: http://www.kurims.kyoto_u.ac.jp /EMIS/proceedings /PME28 /RR/RR303_kaino.pdf

[36] Kaya, E. (2012). Teachers' opinions on the use of social studies classrooms in social studies. Retrieved on 20 September, 2017 from: http://www.edam.com.tr/esp

[37] Letlotlo, B., Kyeleve, I.J., and Liu, Y. (2002). The status of computer usage in Botswana senior secondary school mathematics teaching. In B. Chilisa et al. (Eds.) Mosenodi,Journal of the Botswana Educational Research Association 10(1). 43-54. Gaborone: BERA.

[38] Lowerison, G., Sclater, J., Schmid,R.F. \& Abrami, P.C. (2004). Student perceived effectiveness of computer technology use in postsecondary classrooms.Computers \& Education 47 (2006), pp.465-489 Retreived July 16, 2017 from http://www.researchgate.net/publication/222430943

[39] Maddison, J. (1983). Education in the MicroElectronic Era. Open University Press.

[40] Marwan, A. (2008). Teachers' Perceptions of Teaching with Computer Technology: Reasons for Use and Barriers in Usage. International Journal of Instructional Technology and Distance learning. Volume 5(6), pp. http://www.itdl.org/Journal/jun_08/article04.htm

[41] McCombs, B. L. (2000). Assessing the role of educational technology in the teaching and learning process: A learner centered perspective. The Secretarys Conference on Educational Technology 2000. Retrieved June 28, 2015.

[42] Mertens, D. M. (1998). Research Methods in Education and Psychology. Integrating Diversity with Quantitative \& Qualitative Approaches. London: Sage Publications.

[43] Mmatli, S. (1992). Computer usage in Botswana Senior secondary schools. Unpublished B.Ed Special project. University of Botswana, Gaborone, Botswana.

[44] Mooketsi, S., M (2000). An Investigation into the effective use of computers in the teaching of mathematics in senior secondary schools in Botswana. Unpublished M.Ed Thesis. University of Botswana: Gaborone, Botswana.

[45] Moeller, B \& Reitzes, T. (2011) Education Development Center, Inc. (EDC). Integrating Technology with Student-Centered Learning. Quincy, MA: Nellie Mae Education Foundation. Retrieved on August 04, 2017 from http://www.nmefoundation.org/getmedia/befa9751-d8ad-47e9-949d-bd649f7c0044/integrating.

[46] National Research Council (2003). Computer Assisted Education Can Enhance Learning. In J.D. Torr(Ed.), Computers and Education (pp. 22-36).San Francisco: Thomson Gale.

[47] National Educational Technology Standards for Students, International Society for Technology in Education, NETSS, ISTE ( 2007). International Society for Technology in Education. Retrieved March 22, 2017 from http://www.iste.org/Content/NavigationMenu/NETS/ForStudents/2007Standards/NETS_ for_ Students_2007.htm.

[48] NCTM (2000). Principles and standards for school mathematics. Number and operations standards. Reston VA: NCTM. Retrieved February 10, 2017, from http://standards.nctm.org/document/ appendix/numb.htm

[49] Nkhwalume, A. (2013). Challenges of integrating ICTs into the mathematics curricula in the SADC region: The case of Botswana. Retrieved on 20 September, 2017, from: www.savap.org.pk/journals/ARInt .$/$ Vol.4(2)/2013(4.2-35).pdf

[50] Noeth, R.J. \& Volkov, B.B. (2004 ). Evaluating the Effectiveness of Technology in our Schools: ACT POLICY REPORT. Retrieved on August 05, 2017 from https://www.act.org/research/policymakers/pdf/ school_tech.pdf

[51] Okojie, M. C., Olinzock, A. A., \& Okojie-Boulder, T. C. (2006). The pedagogy of technology integration. Journal of Technology Studies, 32(2), 66-71. Retrieved on August 05, 2017 from https://files.eric.ed.gov/ fulltext/EJ847571.pdf 
[52] Ritzhaupt, A.D, Dawson, K and Cavanaugh, C (2012). An investigation of factors influencing student use of technology in K-12 classrooms using path analysis. Journal of Educational Computing Research. 46 (6), 229-254. Retrieved on 12 August 2017 from: http:/ehis.ebscohost.com/eds

[53] Rundell, M. (2009)(ed). Macmillan English Dictionary. Macmillan Publishers Limited. Retrieved on September 01, 2017 from: http://www.macmillandictionary.com/

[54] Ruthven, K. (1996). Calculators in the mathematics Curriculum: The scope of Personal Computational Technology. In A.J. Bishop et al. (Eds), International Handbook of Mathematics Education, 435468.London: Kluwer Acadmeci Publishers.

[55] Sabzian, F. \& Gilakjani, A.P. (2013). Teachers' Attitudes about Computer Technology Training, Professional Development, Infusion, Experience, Anxiety, and Literacy in English Language Teaching and Learning. International Journal of Applied Science and Technology Vol. 3 (1), pp.67-75. Retrieved on August 12, 2017 from http://www.ijastnet.com/journals/Vol_3_No_1_January_2013/9.pdf .

[56] Saunders,W.L.(1992). "The constructivist perspective: Implications and teaching strategies or science," School Science Mathematics, vol. 92, no. 3, pp. 136-141. DOI: 10.1111/j.1949-8594.1992.tb12159.x

[57] Schacter, J., \& Fagnago, C. (1999). Does computer technology improve student learning and achievement? How, when, and under what conditions?. Journal of Educational Computing Research, 20(4), 329-343.

[58] Schmidt, D. A. (1995). Use and infusion of computer-related technology in teaching by preservice teacher education faculty. Unpublished Ph.D. dissertation. Iowa State University, Ames, IA.http://www.editlib. org/p/10691/proceeding_10691.pdf

[59] Serumola, L.B (1992). Introduction to the use of computers to assist in the teaching and learning of Physics in Senior Secondary schools within Gaborone. Unpublished B.Ed Special project. University of Botswana, Gaborone, Botswana.

[60] Taylor, L. C. (1980). The Computer in the school. Tutor, Tool, Tutee. Teacher's College Press.

[61] Wiersma, W., \& Jurs, S. G. (2005). Research methods in education (8th ed.). Boston, MA: Allyn \& Bacon.

[62] Winter, R. (1996). "Some Principles and Procedures for the Conduct of Action Research." New Directions in Action Research. Retrieved on 02 September 2017, from: http://www.web.net/robrien/papers/arfinal .html

[63] Wright, V. H and Wilson, E.K. (2011). Teachers' use of technology: lessons learned from the teacher education program classroom. SRATE Journal. 20(2), 48-60. Retrieved 21 September 2017 from: http://files.eric.ed.gov/fulltext/EJ959529.pdf.Zimmerman, W. \& Cunningham, S. (1991) Editors' Introduction: WhatIs Mathematical Visualization? In: Zimmermann, W.; Cunningham, S. (eds.) Visualization in teaching and learning mathematics, 1-8.

Citation: End Salani. "The Extent of Technology Infusion in the Junior Secondary School Math \& Science Curriculum: Students Views”. International Journal of Humanities Social Sciences and Education (IJHSSE), vol 5, no.12, 2018, pp. 151-169. doi:http:// dx.doi.org/10.20431/2349-0381.0512016.

Copyright: (C) 2018 Authors. This is an open-access article distributed under the terms of the Creative Commons Attribution License, which permits unrestricted use, distribution, and reproduction in any medium, provided the original author and source are credited. 